\title{
Delisting Risk Analysis: Empirical Evidence from the Thai Listed Companies
}

\author{
Thitivadee Chaiyawat $^{1, *}$, Pornpan Samranruen ${ }^{2}$ \\ ${ }^{1}$ Chualongkorn Business School, Chulalongkorn University, Thailand \\ ${ }^{2}$ UOB Bank, Thailand
}

Copyright $\mathrm{O} 2016$ by authors, all rights reserved. Authors agree that this article remains permanently open access under the terms of the Creative Commons Attribution License 4.0 International License

\begin{abstract}
Delisting has raised an attention in recent years. This is because delisting may post a negatively direct or indirect impact on shareholders, managers, employees, firms, and other stakeholders. Therefore, the needs to understand the symptoms of financial distress in a company and to be able to predict the firm delisting are crucial. The study global objective is to provide a financial operation analysis of The Stock Exchange of Thailand (SET) delisting and listing firms and to uncover the essential variables and risks which may be helpful in monitoring their corporate governance and financial strength. This study uses logistic regression to predict the delisting and listing status. The data used in this study are drawn from the annual reports filed by SET listed firms in Thailand. The sample consists of SET-listed firms in Thailand operating from 2005 to 2011. Scope of data included in this study is listed firms from all industry groups and all sectors except financials industry group classification structured as banking, finance and securities, and insurance sectors. There are many ratios, representing risks, statistically have an effect on delisting. Risks which are likely to affect firm delisting are liquidity risk, operating efficiency risk, profitability risk, leverage risk, credit risk, and financial insolvency risk. The result shows that net working capital to total asset, debt to equity, and gross profit margin statistically significantly have an impact on a delisting of SET-listed firms. Important variables as mentioned above show that liquidity risk, leverage risk, and profitability risk have crucial impacts on firm delisting. The $-2 \log$ likelihood is equal to 17.322 , Cox and Snell $\mathrm{R}^{2}$ is equal to 0.509 , and Nagelkerke $\mathrm{R}^{2}$ is equal to 0.896 . Logistic regression model above is used to classify the delisting and listing during the year of 2005-2010. The result shows that logistic regression model is able to predict $99.1 \%$ correctly classifying listing or surviving firms and $90 \%$ correctly classifying delisting firms. In addition, early warning model of logistic regression is able to predict $100 \%$ correctly classifying listing or surviving firms and $83.3 \%$ correctly classifying delisting firms during their operation in the year of 2011 .
\end{abstract}

Keywords Risk, Delisting, Financial Ratios

\section{Background/Objectives and Goals}

Delisting has raised an attention in recent years. This is because delisting may post a negatively direct or indirect impact on shareholders, managers, employees, firms, and other stakeholders. Jarrell (1984) found that delisted stocks market value declined $9 \%$ on average. This delisting of the listed firms occurred both voluntarily and involuntarily. In the context on voluntary delisting is caused by firm experience of financial distress or having been merged or acquired. Corporate governance has been recognized as one of key factors associated with financial distress (Johnson, et al., 2000).

Therefore, the needs to understand the signs of financial distress and to be able to predict potential firm delisting are crucial. The firm would early understand the risks of delisting and hence would be able to prevent and/or lessen the incoming negative effects on the firm market value.

The prediction of firm delisting employs variety methodologies. A variety of statistical methods and neural networks approach have been applied for predicting problems. Statistical methods; e.g., linear discriminant analysis (LDA), multivariate discriminant analysis (MDA) (Altman, 1968; Sinkey, 1975; Altman, 1977; Lam and Moy, 2002), factor analysis (FA), probit, and logistic regression (logit) (Zmijewski,1984; Martin, 1977; Ohlson, 1980; Thomson, 1991; Gonzalez-Hermosillo, 1999; Kolari, et al., 2002; Montgomery et al., 2005; Canbas, 2005; Konstandina, 2006; Doganay et al., 2006) are widely used. This study employs logistic regression to predict the probability of delisting of a firm from Securities and Exchange Commission (SEC) and attempts to assess the prediction power of logistic regression.

The study global objective is to provide a financial operation analysis of The Stock Exchange of Thailand (SET) delisting and listing firms and to uncover the essential 
variables, representing risks, which may be helpful in monitoring their corporate governance and financial strength. Delisting prediction models can assist SEC regulator determine whether a firm is in danger of failing and distinguish good firms from bad firms. In addition, information on financial distress and delisting can also help auditors decide whether a firm is a "going concern". Detection of firm delisting is of importance to consumers, regulators, legislators, shareholders, bondholders, auditors, and the general public. To know in advance about the factors affecting firm delisting SEC regulator can better assess and monitor the firm's delisting status and take prompt actions. The second purpose of this study is to provide the information about the predicting accuracy performance of the delisting model.

\section{Methods}

The data used in this study are drawn from the annual reports filed by SET-listed firms in Thailand. The sample consists of SET-listed firms in Thailand operating from 2005 to 2011. Scope of data included in this study is listed firms from all industry groups and all sectors except financials industry group classification structured as banking, finance and securities, and insurance sectors. Data are separated into two groups. Firms in the first group are subject to possible delisting and delisting firms which SET had given an advice to accelerate the fulfillment of "The Criteria for Removal from being Delisted" or "The Extension Criteria" during 2005-2014. The delisted firms in the first group are not included firms which are voluntarily delisted, merged, and not complied the SEC regulations; e. g, submitting financial statement beyond deadline, financial statement not met auditors' aspects. Firms in the second group are companies normally operating in the same period and sharing the same value of the assets as firms in group 1. The amount of group 1 and group 2 data are shown in Table 1 .

The dependent variable is not a continuous variable but a binary variable that takes a value of one when a firm is subject to possible delisting or becomes delisted and zero for surviving firms. There are many financial ratios representing risks and having an effect on delisting. Risks which are likely to affect firm delisting are liquidity risk, operating efficiency risk, profitability risk, leverage risk, and other risks (Jensen (1986) and Weir et al. (2005)). This study uses financial ratios to proxy the above risks. Firm may encounter liquidity risk when firm has a chance not having enough cash or cash equivalent to meet the needs of carrying out day-to-day operations. Current ratio (CURRENT), quick ratio (QUICK), and net working capital to total asset ratio (NWCTA) are the proxy for liquidity measurement.

Table 1. Average Asset Size and Amount of Sample in Group 1 and Group 2 Classified by Industry Group during 2005-2011

\begin{tabular}{|c|c|c|c|c|c|}
\hline \multirow{2}{*}{ Year } & \multirow{2}{*}{ Industry Group } & \multicolumn{2}{|c|}{ Group 1} & \multicolumn{2}{|c|}{ Group 2} \\
\hline & & Sample Size & Average Asset (Baht) & Sample Size & Average Asset (Baht) \\
\hline \multirow[t]{4}{*}{2005} & Agro and Food & 4 & $1,326,297$ & 19 & $1,447,585$ \\
\hline & Technology & 2 & $2,212,584$ & 12 & $2,202,144$ \\
\hline & Consumer Products & 1 & 440,295 & 4 & 475,279 \\
\hline & $\begin{array}{l}\text { Property and } \\
\text { Construction }\end{array}$ & 2 & $8,650,184$ & 10 & $8,667,144$ \\
\hline 2007 & Service & 2 & $3,803,117$ & 11 & $3,887,975$ \\
\hline \multirow[t]{4}{*}{2008} & Agro and Food & 1 & 834,334 & 3 & 955,472 \\
\hline & Resources & 1 & $8,959,906$ & 3 & $8,301,273$ \\
\hline & Consumer Products & 1 & $1,186,716$ & 6 & $1,196,305$ \\
\hline & $\begin{array}{l}\text { Property and } \\
\text { Construction }\end{array}$ & 1 & $3,323,609$ & 10 & $3,420,781$ \\
\hline \multirow[t]{3}{*}{2009} & Consumer Products & 2 & $1,501,045$ & 14 & $1,723,428$ \\
\hline & Service & 1 & $1,198,683$ & 7 & $1,176,357$ \\
\hline & Industrials & 1 & $1,880,563$ & 9 & $1,845,849$ \\
\hline 2010 & Industrials & 1 & $3,171,375$ & 7 & $3,123,658$ \\
\hline \multirow[t]{5}{*}{2011} & Technology & 1 & $31,213,616$ & 3 & $29,875,645$ \\
\hline & Resources & 2 & $2,685,421$ & 5 & $2,892,288$ \\
\hline & Service & 1 & $1,470,026$ & 12 & $1,480,729$ \\
\hline & Industrials & 1 & $11,400,258$ & 6 & $11,331,182$ \\
\hline & Consumer Products & 1 & $3,015,096$ & 11 & $3,020,100$ \\
\hline Total & & 26 & $4,273,245$ & 152 & $3,607,448$ \\
\hline
\end{tabular}


Operating inefficiency could be the motivation for delisting. Generally speaking, high asset turnover and high account receivables turnover imply that the company is efficiently deploying asset and generating revenue and vice versa. High account receivables turnover rate could suggest that company has a conservative policy regarding an extension of credit. It also indicates that firm operates efficiently and is able to quickly collect its debt. In addition, high return on asset (ROA) reflects management effectiveness. On the other hand, low ROA discredits a clear picture of corporate financial health. Therefore, this paper uses total asset turnover ratio (TATURN), account receivables turnover ratio ((ARTURN), and return on asset ratio (ROA) as a proxy of operating efficiency risk and credit risk.

Profit margin is one of the most important indicators to company operational success and financial strength. Low profitability problem could damage the company prosperity. Therefore, this paper uses gross profit margin ratio (GPM), operating profit margin ratio (OPM), net profit margin ratio (NPM), earnings before interest and tax to total asset ratio (EBITTA), and retained earnings to total asset ratio (RETA) as a proxy to profitability risk.

The use of financial leverage can generate both positive and negative spillovers to the company's return on equity as a consequence of the increased level of risk. During the business downturn financial leverage can generate a serious impact on company's solvency and may cause a firm delisting. Market capitalization ratio reflects the debt component of a company's capital structure to support company's operation and growth. Market capitalization is likely to negatively correlate to firm delisting. Hence, debt to equity ratio (DE), total liability to total asset ratio (TLTA), and market capital to total liability ratio (MKCTL) are used as a proxy of leverage risk.

Interest coverage ratio (INTC) and earnings before interest and tax to total liability ratio (EBITTL) also should take into account the impact of financial distress. These two ratios measure the margin of safety in order to survive future financial hardship should it become materialized. Company with high debt expense burden faces financial insolvency risk.

Therefore, the financial ratios mentioned above are employed in this study to develop an equation to measure the impact on delisting and listing. That is an equation as follows:

$$
\mathrm{Y}_{\mathrm{i}}=\alpha+\beta_{1} \mathrm{x}_{1 \mathrm{i}}+\beta_{2} \mathrm{x}_{2 \mathrm{i}}+\ldots+\beta_{\mathrm{k}} \mathrm{x}_{\mathrm{ki}}+\varepsilon_{\mathrm{i}}
$$

\section{Logistic Regression}

Logistic regression is part of a category of statistical models called generalized linear model. Logistic regression (logit) model is a type of predictive model that can be used when the target or dependent variable is a dichotomous or categorical variable with two categories. The logit model is based on the logit distribution whose cumulative probability distribution is given by the following expression:

$$
\mathrm{p}_{\mathrm{i}}=\mathrm{F}\left(\mathrm{Z}_{\mathrm{i}}\right)=\mathrm{F}\left(\alpha+\beta \mathrm{X}_{\mathrm{i}}\right)=1 /\left(1+\mathrm{e}^{-\mathrm{Z}_{\mathrm{i}}}\right)=1 /\left(1+\mathrm{e}^{-\left(\alpha+\beta \mathrm{X}_{\mathrm{i}}\right)}\right.
$$

where $\mathrm{p}_{\mathrm{i}}$ is the probability that SET-listed firms in Thailand are subject to possible delisting or becomes delisted, $X_{i}$ is explanatory variables, and $Z_{i}$ is a liner combination the independent variables.

We can then estimate the logit probability model by

$$
Z_{i}=\log \left(p_{i} / 1-p_{i}\right)=\alpha+\beta X_{i}
$$

The logistic function with $\mathrm{z}$ on the horizontal axis and $\mathrm{f}(\mathrm{z})$ on the vertical axis is shown in Figure 1 below.

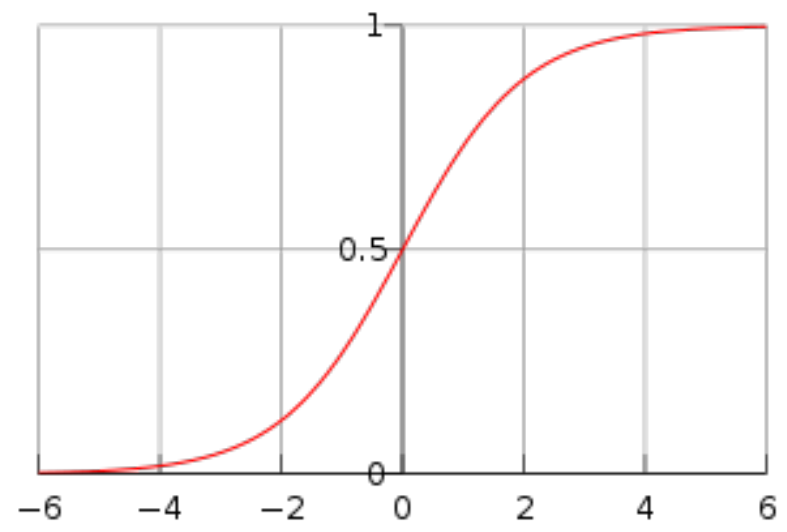

Source: Wikipedia

Figure 1. Logistic Function

In this paper it is used that $P_{i}$ takes a value of 1 or $y_{i}=$ 1 when it is a delisting and zero otherwise. Probability of not delisting or surviving is $1-P_{i}$ and thus $y_{i}=0$. Probability function is as follows:

$$
f\left(y_{i}\right)=P_{i}^{y_{i}}\left(1-P_{i}\right)^{1-y_{i}} \quad y_{i}=0,1
$$

This study wants to analyze the factors which have an impact on $P_{i}$ which can separate into two parts:

1. Attributes of the choice represented by $z_{i}$

2. Attributes of the individual represented by $w_{i}$

$U_{i 0}$ and $U_{i 1}$ are utility function of individual $i$ of non-chosen alternative and chosen alternative, respectively. $\bar{U}$ would represent the average utility of individual which can be stated as follows:

$$
\begin{aligned}
& U_{i 0}=\bar{U}_{i 0}+e_{i 0}=z_{i 0}^{\prime} \delta+w_{i}^{\prime} \gamma_{0}+e_{i 0} \\
& U_{i 1}=\bar{U}_{i 1}+e_{i 1}=z_{i 1}^{\prime} \delta+w_{i}^{\prime} \gamma_{1}+e_{i 1}
\end{aligned}
$$

Individual would determine for any chosen alternative when $U_{i 1}>U_{i 0}$ or $y_{i}{ }^{*}=U_{i 1}-U_{i 0}$. Then $y_{i}$ and $y_{i}^{*}$ would be as shown below.

$$
y_{i}=\left\{\begin{array}{lll}
1 & \text { if } & y^{*}{ }_{i}>0 \\
0 & \text { if } & y^{*}{ }_{i} \leq 0
\end{array}\right.
$$




$$
\begin{gathered}
y^{*}{ }_{i}=\left(z_{i 1}-z_{i 10}\right)^{\prime} \delta+w_{i}^{\prime}\left(\gamma_{1}-\gamma_{0}\right)+\left(e_{i 1}-e_{i 0}\right) \\
=\left[\left(z_{i 1}-z_{i 0}\right)^{\prime} \delta, w_{i}^{\prime}\right]\left[\begin{array}{c}
\delta \\
\gamma_{1}-\gamma_{0}
\end{array}\right]+e_{i}^{*} \\
=x_{i}^{\prime} \beta+e^{*}{ }_{i}
\end{gathered}
$$

when $x_{i}$ is explanatory variables vector

$\beta$ is coefficient vector

$e^{*}{ }_{i}$ is error vector

Probability of $y_{i}=1$ would be equal to as follows:

$$
P_{i}=\operatorname{Pr}\left[y_{i}=1\right]=\operatorname{Pr}\left[y_{i}^{*}>0\right]=\operatorname{Pr}\left[e_{i}^{*}>-x_{i}^{\prime} \beta\right]
$$

Error term would have variety of distributions. If error term has a normal distribution, cumulative probability function (c.d.f.) is as follows:

$$
F(t)=\int_{-\infty}^{t}(2 \pi)^{-1 / 2} \exp \left\{-x^{2} / 2\right\} d x
$$

Therefore, it has to be estimated with Probit function and the cumulative probability function (c.d.f.) is as follows:

$$
F(t)=\frac{1}{1+\exp (-t)}
$$

It makes $F(-t)=1-F(t)$ so that probability of $y_{i}=1$ is as follows:

$$
\begin{gathered}
P_{i}=\operatorname{Pr}\left[e_{i}^{*}>-x_{i}^{\prime} \beta\right] \\
=1-\operatorname{Pr}\left[e_{i}^{*} \leq x_{i}^{\prime} \beta\right]=1-F\left(-x_{i}^{\prime} \beta\right) \\
P_{i}=F\left(x_{i}^{\prime} \beta\right)
\end{gathered}
$$

\section{Explanatory Variables}

We postulate that the possibility of delisting and delisting of SET-listed firms in Thailand is a function of several variables. Explanatory variables are financial ratios which encompass measures of profitability, leverage, liquidity, operating efficiency, financial solvency, and decomposition of assets and liabilities used here to examine the delisting of the SET-listed firms in Thailand.

Factors hypothesized to have an impact on the SET-listed firms in Thailand's Delisting

SET-listed firms in Thailand are the "risk-takers"1. They do concern about the liquidity, profitability, growth and etc. The following discussed variables were previously tested and found to have a significant relationship with firms' delisting.

1Banks are said to serve as "financial intermediaries".

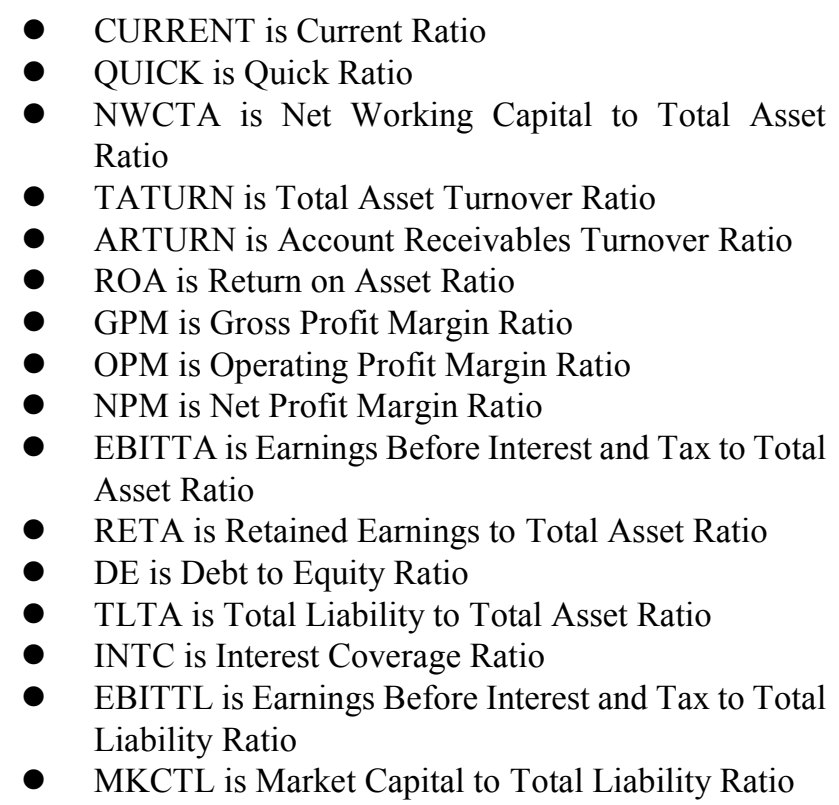

Dependent Variables

The dependent variable is not a continuous variable but a binary variable that takes a value of one when a SET-listed firm in Thailand is subject to possibly delisted or becomes delisted and zero otherwise. That is the dependent variable could be interpreted as the probability that firm will become delisting.

\section{Results}

Hypotheses and Expected Results

Total of 16 factors expected to influence delisting of SET-listed firms are to be tested in this study. The hypotheses are as follows:

$\mathrm{H}_{1}$ : Current asset to current liability is negatively correlated with SET-listed firm's delisting. The low current ratio reflects liquidity risk.

$\mathrm{H}_{2}$ : Current asset excluding inventory to current liability is negatively correlated with SET-listed firm's delisting. The low quick ratio reflects liquidity risk.

$\mathrm{H}_{3}$ : Current asset minus current liability to total asset is negatively correlated with SET-listed firm's delisting. The low net working capital ratio reflects liquidity risk.

Liquidity risk causes firm inability to pay debt and having a poor expense performance. This issue may create firms' insolvency.

$\mathrm{H}_{4}$ : Sales to total asset is negatively correlated with SET-listed firm's delisting. The high asset turnover reflects high operating efficiency.

$\mathrm{H}_{5}$ : Sales credit to account receivables is negatively correlated with SET-listed firm's delisting. The low account receivable turnover reflects high credit risk and low operating efficiency.

Credit risk can generate bad debt to the firms and finally may drive firms in a situation of default risk. Low 
receivables turnover rate indicates company's collection of account receivables is inefficient. The low proportion of quality receivables could provoke cash flow illiquidity.

$\mathrm{H}_{6}$ : Net profit to asset is negatively correlated with SET-listed firm's delisting. The low return on asset ratio (ROA) reflects profitability risk.

$\mathrm{H}_{7}$ : Sales minus cost of goods sold to sales is negatively correlated with SET-listed firm's delisting. The low gross profit margin reflects profitability risk.

$\mathrm{H}_{8}$ : Sales minus cost of goods sold and operating expense to sales is negatively correlated with SET-listed firm's delisting. The low operating profit margin reflects profitability risk.

$\mathrm{H}_{9}$ : Net profit to sales is negatively correlated with SET-listed firm's delisting. The low net profit margin reflects profitability risk.

$\mathrm{H}_{10}$ : Earnings before interest and tax (EBIT) to total asset is negatively correlated with SET-listed firm's delisting. The low EBIT margin reflects profitability risk.

$\mathrm{H}_{11}$ : Retained earnings to total asset are negatively correlated with SET-listed firm's delisting. The low net earnings should reflect profitability risk and even may cause a slow-growing business due to a limitation to retain some earnings for firm's reinvestment. This may immediately generate a negative impact on share price and thus firms may face a plenty of hardship.

Profitability risk levies firms limited financial capacity and business expansion. High growth rate with low financial capacity causes high borrowing cost. Therefore, low profitability may induce firm's financial distress and a major challenge of surviving. Consequently, a business success may enormously be questioned.

$\mathrm{H}_{12}$ : Debt to equity is positively correlated with SET-listed firm's delisting. The high DE ratio reflects leverage risk.

$\mathrm{H}_{13}$ : Total liability to total asset is positively correlated with SET-listed firm's delisting. The high liability ratio reflects leverage risk.

$\mathrm{H}_{14}$ : Market value to total liability is negatively correlated with SET-listed firm's delisting. The firm's high market value reflects lower strategic risk. Lower proportion of debt could increase company's financial flexibility. That is a reduction in leverage risk and the risk of insolvency.

Financial leverage risk can be a double-edged sword of a firm. The material risk would arise when company's ROA does not exceed the interest payment on loans. This would lead a crucial impact on diminishing profits. Therefore, confidence in firm's financial stability could be badly shaken.

$\mathrm{H}_{15}$ : Earnings before interest and tax to cost of capital is negatively correlated with SET-listed firm's delisting. The high interest coverage capability reflects interest payment performance.

$\mathrm{H}_{16}$ : Earnings before interest and tax to liability is negatively correlated with SET-listed firm's delisting. The high value of this ratio suggests that company has strong capability to pay off its incurred debt.

Firm with an outstanding ability to pay back its debt shows a good determinant of strong financial health and liquidity position. Therefore, listing firm with a sound payment capacity would experience low insolvency risk.

Table 2 summarizes a result of an early warning system to predict firm delisting by using stepwise logistic regression. Statistically significant variable coefficients, S.E., Wald Test statistics, P-Value, and Exp (B) coefficients are presented below.

Table 2. Coefficient Value, P-Value and the Sign of Correlation Coefficient of Stepwise Logistic Regression for Predicting Delisting, 2005-2011

\begin{tabular}{|c|c|c|c|c|c|}
\hline $\begin{array}{c}\text { Explanatory } \\
\text { Variable }\end{array}$ & $\begin{array}{c}\text { Coefficient } \\
\text { Value }\end{array}$ & S.E. & Wald & P-Value & $\begin{array}{c}\text { Exp } \\
(\mathrm{B})\end{array}$ \\
\hline NWCTA & -9.648 & 4.097 & 5.546 & $0.019^{* *}$ & 0.000 \\
\hline DE & 1.66 & 0.751 & 4.879 & $0.027^{* *}$ & 5.258 \\
\hline GPM & -0.13 & 0.062 & 4.486 & $0.034^{* *}$ & 0.878 \\
\hline Constant & -4.919 & 1.854 & 7.040 & $0.008^{* * *}$ & 0.007 \\
\hline
\end{tabular}

Note: *** Significant at 1 percent level

** Significant at 5 percent level

* Significant at 10 percent level

Net working capital to total asset ratio, debt to equity ratio, and gross profit margin ratio have statistically significantly influenced SET-delisted firms. Important variables as mentioned above show that liquidity risk, leverage risk, and profitability risk have crucial impacts on firm delisting. The $-2 \log$ likelihood is equal to 17.322 , Cox and Snell $\mathrm{R}^{2}$ is equal to 0.509 , and Nagelkerke $R^{2}$ is equal to 0.896 . The model of delisting probability of SET-listed firms can be stated below.

$$
\begin{aligned}
& Y=\log (\text { OddRatio })=-4.919-9.648 N W C T A+ \\
& +1.66 D E-0.13 G P M
\end{aligned}
$$

Value of $Y$ in the equation of $F(Y)=\frac{1}{1+\exp (-Y)}$ would lead to the probability that firms would be delisted. Different critical values show different levels of correction percentage in forecasting SET-listed firm delisting and surviving. Logistic regression model above is used to classify the delisting and listing in the training set during the year of 2005-2010. The result shows that an early warning model of logistic regression is able to predict $97.8 \%$ correctly classifying listing or surviving and delisting. The prediction of testing set, listing and delisting firms operating in the year of 2011 , is $97.7 \%$ correctly. The results are summarized in Table 3. 
Table 3. Number of Firms and Correction Percentage of Firm Listing and Delisting Prediction during 2005-2011

\begin{tabular}{|c|c|c|c|c|}
\hline \multirow[b]{2}{*}{ Data Set } & Observed & \multicolumn{2}{|c|}{ Predicted } & \multirow{2}{*}{ Correction } \\
\hline & & $\begin{array}{c}\text { Number of Listing } \\
\text { (Percentage) }\end{array}$ & $\begin{array}{c}\text { Number of Delisting } \\
\text { (Percentage) }\end{array}$ & \\
\hline \multirow{3}{*}{ Training Set } & Listing & $\begin{array}{c}114 \\
(99.1 \%) \\
\end{array}$ & $\begin{array}{c}1 \\
(0.9 \%)\end{array}$ & 99.1 \\
\hline & Delisting & $\begin{array}{c}2 \\
(10 \%) \\
\end{array}$ & $\begin{array}{c}18 \\
(90 \%) \\
\end{array}$ & 90 \\
\hline & \multicolumn{3}{|c|}{ Overall Correction Percentage of Classification } & 97.8 \\
\hline \multirow{3}{*}{ Testing Set } & Listing & $\begin{array}{c}37 \\
(100 \%) \\
\end{array}$ & $\begin{array}{c}0 \\
(0 \%) \\
\end{array}$ & 100 \\
\hline & Delisting & $\begin{array}{c}1 \\
(16.7 \%) \\
\end{array}$ & $\begin{array}{c}5 \\
(83.3 \%) \\
\end{array}$ & 83.3 \\
\hline & \multicolumn{3}{|c|}{ Overall Correction Percentage of Classification } & 97.7 \\
\hline
\end{tabular}

The result in Table 3 above shows that an early warning model of logistic regression is able to predict $99.1 \%$ correctly classifying listing firms and $90 \%$ correctly classifying delisting firms in training set which is comprised of 115 listing and 20 delisting firms during the period of 2005-2010. The percentage correction is slightly different in the testing set which consists 37 listing or surviving and 6 delisting firms in the year of 2011. The model is able to perfectly predict listing firms while only able to predict $83.3 \%$ correctly classifying delisting firm in the testing set.

The goodness of fit of logistic regression model is assessed by using Hosmer and Lemeshow test and the hypotheses are as follows:

$H_{0}$ : The logistic regression model fits the data

$H_{1}$ : The logistic regression model doesn't fit the data with a significance at 5 percentage level

The result shows that $\mathrm{p}$-value is greater than 0.05 which means that logistic regression model is appropriate and can be used to classify firm listing and delisting. The result of $\chi^{2}$ test statistics is shown in Table 4 .

Table 4. Hosmer and Lemeshow Testing Goodness of Fit of Logistic Regression Model by using $\chi^{2}$ Statistics

\begin{tabular}{|c|c|c|}
\hline Chi-square $\left(\chi^{2}\right)$ & Df & p-value \\
\hline 0.068 & 8 & 1.000 \\
\hline
\end{tabular}

This study examines an impact of risks on firm delisting. The result shows that liquidity risk, leverage risk, and profitability risk have crucial effects on delisting. Higher net working capital enhances survival probability of listed firms. In addition, firms with higher gross profit margin have a lower probability of delisting. On the other hand, listed firms have a negative impact from high leverage. High debt to equity will provoke firms to be delisted.

\section{REFERENCES}

[1] Altman, E. I. (1968). Financial Ratios, Discriminant Analysis and the Prediction of Corporate Bankruptcy, The Journal of Finance, 23, 589-609.

[2] Altman, E. I. (1977). Predicting Performance in the Savings and Loan Association Industry, Journal of Monetary Economics, 3, 443-466.

[3] Canbas, S., Cabuk, A. and Kilic, S. B. (2005). Prediction of Commercial Bank Failure via Multivariate Statistical Analysis of Financial Structure: The Turkish Case, European Journal of Operational Research, 166, 528-546.

[4] Doganay, M. M., Ceylan, N. B., and Aktas, R. (2006). Predicting Financial Failure of the Turkish Banks, Annals of Financial Economics, 1, 97-117.

[5] Gonzalez-Hermosillo, B. (1999). Determinants of Ex-Ante Banking System Distress: A Macro-Micro Empirical Exploration of Some Recent Episodes. International Monetary Fund Working Paper No. 33.

[6] Jarrell, G. A. (1984). The Stock Price Effects of NYSE Delisting for Violating Corporate Governance Rules. U.S. Securities and Exchange Commission Working Paper.

[7] Jensen, M. C. (1986). Agency Cost of Free Cash Flow, Corporate Governance, and Takeovers, American Economic Review, 76(2).

[8] Johnson, S., Boone., P. Breach, A. and Friedman, E. (2000). Corporate Governance in the Asian Financial Crisis, Journal of Financial Economics, 58, 141-186.

[9] Kolari, J., Glennon, D., Shin, H., and Caputo, M. (2002). Predicting Large US Commercial Bank Failures, Journal of Economics and Business, 54(321), 361-387.

[10] Konstandina, N. (2006). Probability of Bank Failure: The Russian Case. Economic Education and Research Consortium Working Paper No. 01.

[11] Lam, K. F. and Moy, J. W. (2002). Combining Discriminant Methods in Solving Classification Problems in Two-Group Discriminant Analysis. European Journal of Operational Research, 138, 294-301.

[12] Martin, D. (1977). Early Warning of Bank Failure: A Logit regression Approach, Journal of Banking and Finance, 1, 249-276. 
[13] Montgomary, H., Hanh, T. B., Santoso, W., and Besar, D. S. (2005). Coordinated Failure? A Cross-Country Bank Failure Prediction Model. ADB Institute Discussion Paper No. 32.

[14] Ohlson, J. A. (1980). Financial Ratios and Probabilistic Prediction of Bankruptcy, Journal of Accounting Research, $18,109-131$.

[15] Sinkey, J. F. (1975). A Multivariate Statistical Analysis of the Characteristics of Problem Banks, The Journal of Finance, 30 (1), 21-36.
[16] Thomson, J. B. (1991). Predicting Bank Failures in the 1980s, Economic Review-Federal Reserve Bank of Cleveland, 27(1), 9.

[17] Weir, C. M., Laing, D., and Wright, M. (2005). Undervaluation, Private Information, Agency Cost and the Decision to go Private, Applied Financial Economics, 15, 947-961.

[18] Zmijewski, M. E. (1984). Methodological Issues Related to the Estimation of Financial Distress Prediction Models, Journal of Accounting Research, 22, 59-82. 